\title{
THE INFLUENCE OF DIMETHOXYBENFLURON ON BIOCHEMICAL AND HAEMATOLOGICAL PARAMETERS IN RABBITS
}

\author{
Jarmila Macháčková ${ }^{1}$, Vladimír Geršl ${ }^{1}$, Radomír Hrdina ${ }^{2}$, Milan Nobilis $^{3}$, Vladimír Palička ${ }^{4}$
}

Charles University in Prague, Faculty of Medicine in Hradec Králové: Department of Pharmacology ${ }^{1}$; Charles University in Prague, Faculty of Pharmacy in Hradec Králové: Department of Pharmacology and Toxicology ${ }^{2}$; Institute of Experimental Biopharmaceutics, Czech Academy of Sciences in Hradec Králové3; University Teaching Hospital in Hradec Králové: Department of Clinical Biochemistry ${ }^{4}$

Summary: The influence of repeated i.v. administration of dimethoxybenfluron (NO-1-B) (12 or $24 \mathrm{mg}$ base/kg once weekly, 10 weeks) on biochemical and haematological parameters were studied in rabbits in vivo. No significant changes were mostly found in the serum ion levels between the dimethoxybenfluron and the control groups, as well as in most of other biochemical parameters (including total protein and albumin levels). Nevertheless, the lower dose of dimethoxybenfluron caused an increase in the glucose level. Furthermore, no significant changes were mostly present also in haematological parameters in the dimethoxybenfluron groups of rabbits (a mild decrease in thrombocytes and leucocytes). The results of our study support an assumption of good tolerance of dimethoxybenfluron from the viewpoint of its influence on biochemical and haematological parameters in rabbits and may be considered of importance for a possible therapeutic use of the derivatives.

Key words: Antineoplastic drugs; Benfluron; Dimethoxybenfluron; Rabbit; Biochemistry; Haematology

\section{Introduction}

Possible biochemical and haematological adverse effects of new substances, potentially used as antitumour agents, may be a limiting factor of their therapeutic use. Benfluron (5-[2]-(N,N-dimethylamino)ethox[y]-7-oxo7H-benzo[c]fluorene - a typical compound of U.S. patent application Ser. No. 417,834) was shown to posses antitumour activity in both in vitro (11) and in vivo studies (10). Nevertheless, more or less marked changes (though mostly reversible ones) of the biochemical and haematological parameters were described $(9,14)$. A synthetic derivative of benfluron - 3,9-dimethoxy-benfluron hydrochloride (Compound Code NO-1-B, Institute of Experimental Biopharmaceutics, Czech Academy of Sciences in Hradec Králové, Czech Republic) - is a new intercalating agent. The molecular formula of NO-1-B is $\mathrm{C}_{23} \mathrm{H}_{24} \mathrm{O}_{4} \mathrm{NCl}$ and molecular weight 413.9. Its activity in neoplastic diseases in animals has been described (e.g., in leukaemia L 1210 - 8). As unfavourable effects may limit a possible use of this drug in human medicine, our study aimed to obtain a complex information about the biochemical and haematological changes following the repeated administration of equieffective and equitoxic doses of NO-1-B in rabbits in vivo.

\section{Material and methods}

Medium size Chinchilla male rabbits of an average weight of $3.2 \pm 0.22 \mathrm{~kg}$ at the beginning of the experiment were used. All animals were fed dry pellets (formulated for rabbits) and water ad lib. The animals were maintained an in air-conditioned room. The experiment followed the Law of the Czech National Council for the protection of animals against cruelty and was under the supervision of the Ethics Committee of the Medical Faculty, Charles University, Hradec Králové.

The animals were divided to three groups. The control group (fifteen rabbits) was given saline ( $1 \mathrm{ml} / \mathrm{kg}$, i.v.). The lower dose of NO-1-B (12 mg base/ $\mathrm{kg}$ i.v.) was administered to seven animals (NO-1-B 12 group), six animals were administered a larger dose of the drug - $24 \mathrm{mg}$ base $/ \mathrm{kg}$ i.v. (NO-1-B 24 group).

Drugs used in the study were administered once a week, intravenously (over $30 \mathrm{~s}$ ) into the marginal ear vein for ten weeks. The period of the administration of drugs was selected on the basis of previous studies (4). Collection of the blood samples (from the ear artery) was performed during anaesthesia (ketamine $50 \mathrm{mg} / \mathrm{kg}$ i.m.) in intervals: „1“ (the control value at the beginning of the experiment; before the 1 st administration of the drug); „2“ (before the 5th admi- 
nistration of the drug) and „3“ (at the end of experiment; one week after the last administration of the drug). At the end of the follow-up period (5-7 days after the last administration of the drug), animals were killed with i.v. pentobarbital overdosing. After the sacrifice of rabbits, gross autopsy was performed and the heart was excised.

Biochemical parameters were determined in arterial blood samples in plasma/serum with standard biochemical methods using an automatic analyzer HITACHI, 717 Japan. Haematological parameters were determined using an analyzer Coulter T890 (USA).

Noninvasive polygraphic recordings of the systolic time intervals in previously anaesthetised (ketamine in a dose of $50 \mathrm{mg} / \mathrm{kg}$ i.m.) and restrained rabbits were used to assess the cardiac function during the experiment as described previously (3). The biological and toxicological parameters (changes in the weight of rabbits and their survival) were followed up during the experiment.

Drugs used in the study:

- NO-1-B (3,9-dimethoxybenflurone) in the form of base, M.w. $=413.9$, dissolved in Natrium chloratum sol. isotonica $\left(40^{\circ} \mathrm{C}\right.$, ultrasonic bath)

- Ketaminum hydrochloridum (Narkamon 5\%, Léčiva, Czech Republic), $50 \mathrm{mg} / \mathrm{kg}$ i.m.

- Natrium chloratum sol. isotonica (Hoechst-Biotika, Slovak Republic), 1,0 ml/kg

- Pentobarbital (NEMBUTAL, Abbott, USA), 30 mg / kg i.v.

\section{Statistical analysis:}

Statistical evaluation of values was performed using a paired t-test (within one group) and by means of an unpaired test ANOVA $\leq$ (comparison of different groups) for the level of significance $\mathrm{p} \leq 0.05$. Values are expressed as mean \pm S.E.M. Significant differences of individual values are marked in the following manner: „*"= significant differences to the initial value within a group; „C“= significant differences between the value of the NO-1-B groups and the control value; „B“= significant differences between NO-1-B groups.

\section{Results}

\section{Biochemical parameters}

No consistent differences were found between control and NO-1-B animals. Though significant, a mild decrease in the concentration of the $\mathrm{K}^{+}, \mathrm{Ca}^{2+}, \mathrm{Cl}^{-}$and phosphate was found in NO-1-B groups. Lower values of bilirubin and ALP were found in both NO-1-B groups at the end of experiment. Mostly no significant changes were found in the value of urea, creatinine, lactate dehydrogenase (LD), alanine aminotransferase (ALT), aspartate aminotransferase (AST), creatinine kinase $(\mathrm{CK})$, triglycerides $(\mathrm{TG})$ and C-reactive protein (CRP). The lower dose of NO-1-B induced a significant increase in glucose, which was significantly different from the control group. No significant changes or a mild increase in protein and albumin levels were found after NO1-B administration (Table 1).
Tab. 1: Changes in biochemical parameters.

\begin{tabular}{|c|c|c|c|c|}
\hline \multirow{2}{*}{ Parameter } & \multirow[t]{2}{*}{ Group } & \multicolumn{3}{|c|}{ Time interval } \\
\hline & & 1. & 2. & 3. \\
\hline \multirow{3}{*}{$\begin{array}{l}\text { Sodium } \\
(\mathrm{mmol} / \mathrm{l})\end{array}$} & $\mathrm{C}$ & $141.7 \pm 0.7$ & $143.4 \pm 0.7$ & $144.3 \pm 0.8^{*}$ \\
\hline & NO-1-B 12 & $139.0 \pm 0.5^{\mathrm{C}}$ & $140.4 \pm 0.6^{*} \mathrm{C}$ & $138.6 \pm 1.0^{\mathrm{C}}$ \\
\hline & NO-1-B 24 & $140.2 \pm 0.7$ & $140.5 \pm 0.3^{\mathrm{C}}$ & $142.2 \pm 1.3$ \\
\hline \multirow{3}{*}{$\begin{array}{l}\text { Potassium } \\
(\mathrm{mmol} / \mathrm{l})\end{array}$} & $\mathrm{C}$ & $4.0 \pm 0.2$ & $3.6 \pm 0.1$ & $3.3 \pm 0.1^{*}$ \\
\hline & NO-1-B 12 & $3.8 \pm 0.2$ & $3.8 \pm 0.1$ & $3.3 \pm 0.1^{*}$ \\
\hline & NO-1-B 24 & $3.8 \pm 0.1$ & $3.8 \pm 0.1$ & $3.2 \pm 0.1^{*}$ \\
\hline \multirow{3}{*}{$\begin{array}{l}\text { Chloride } \\
(\mathrm{mmol} / \mathrm{l})\end{array}$} & $\mathrm{C}$ & $102.2 \pm 1.0$ & $104.5 \pm 0.8$ & $103.0 \pm 1.1$ \\
\hline & NO-1-B 12 & $105.1 \pm 0.5$ & $106.0 \pm 0.9$ & $101.3 \pm 0.6^{*}$ \\
\hline & NO-1-B 24 & $106.3 \pm 0.5^{\mathrm{C}}$ & $106.3 \pm 1.5$ & $105.8 \pm 0.7^{\mathrm{B}}$ \\
\hline \multirow{3}{*}{$\begin{array}{l}\text { Calcium } \\
(\mathrm{mmol} / \mathrm{l})\end{array}$} & $\mathrm{C}$ & $3.2 \pm 0.04$ & $3.2 \pm 0.1$ & $3.3 \pm 0.08$ \\
\hline & NO-1-B 12 & $3.3 \pm 0.02$ & $3.2 \pm 0.0$ & $3.1 \pm 0.02^{*}$ \\
\hline & NO-1-B 24 & $3.3 \pm 0.03$ & $3.3 \pm 0.1$ & $3.1 \pm 0.03^{*}$ \\
\hline \multirow{3}{*}{$\begin{array}{l}\text { Magnesium } \\
(\mathrm{mmol} / \mathrm{l})\end{array}$} & $C$ & $0.9 \pm 0.1$ & $1.0 \pm 0.1$ & $1.0 \pm 0.0$ \\
\hline & NO-1-B 12 & $1.0 \pm 0.0$ & $1.1 \pm 0.1$ & $1.2 \pm 0.1$ \\
\hline & NO-1-B 24 & $0.9 \pm 0.1$ & $0.9 \pm 0.0$ & $0.9 \pm 0.0^{\mathrm{B}}$ \\
\hline \multirow{3}{*}{$\begin{array}{l}\text { Phosphate } \\
(\mathrm{mmol} / \mathrm{l})\end{array}$} & $\mathrm{C}$ & $1.9 \pm 0.1$ & $1.5 \pm 0.1^{*}$ & $1.4 \pm 0.1^{*}$ \\
\hline & NO-1-B 12 & $2.2 \pm 0.1$ & $2.0 \pm 0.2^{\mathrm{C}}$ & $1.9 \pm 0.2^{\mathrm{C}}$ \\
\hline & NO-1-B 24 & $2.1 \pm 0.1$ & $1.8 \pm 0.1^{*}$ & $1.6 \pm 0.1^{*}$ \\
\hline \multirow{3}{*}{$\begin{array}{l}\text { Glucose } \\
(\mathrm{mmol} / \mathrm{l})\end{array}$} & $\mathrm{C}$ & $10.8 \pm 0.9$ & $10.0 \pm 0.6$ & $13.2 \pm 0.7$ \\
\hline & NO-1-B 12 & $9.4 \pm 0.6$ & $9.9 \pm 0.6$ & $19.9 \pm 2.1^{*} \mathrm{C}$ \\
\hline & NO-1-B 24 & $10.2 \pm 1.0$ & $10.7 \pm 0.8$ & $13.3 \pm 1.3^{* \mathrm{~B}}$ \\
\hline \multirow{3}{*}{$\begin{array}{l}\text { Urea } \\
(\mathrm{mmol} / \mathrm{l})\end{array}$} & 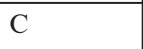 & $7.9 \pm 0.3$ & $8.6 \pm 0.4$ & $7.8 \pm 0.3$ \\
\hline & NO-1-B 12 & $7.2 \pm$ & $7.6 \pm 0.4$ & $7.0 \pm 0.2$ \\
\hline & NO-1-B 24 & $6.9 \pm 0.6$ & $7.1 \pm 0.4$ & $6.8 \pm 0.6$ \\
\hline \multirow{3}{*}{$\begin{array}{l}\text { Creatinine } \\
(\mu \mathrm{mol} / \mathrm{l})\end{array}$} & $\mathrm{C}$ & $91.2 \pm 4.1$ & $96.3 \pm 2.8^{*}$ & $97.4 \pm 4.1$ \\
\hline & NO-1-B 12 & $95.0 \pm$ & $97.0 \pm 7.2$ & $87.4 \pm 5.2$ \\
\hline & NO-1-B 24 & $88.5 \pm 5.0$ & $90.3 \pm 3.9$ & $85.2 \pm 5.7$ \\
\hline \multirow{3}{*}{$\begin{array}{l}\text { Uric acid } \\
(\mu \mathrm{mol} / 1)\end{array}$} & $\mathrm{C}$ & $12.5 \pm 1.8$ & $7.3 \pm 1.0^{*}$ & $9.6 \pm 2.3$ \\
\hline & NO-1-B 12 & $10.8 \pm 3.0$ & $7.6 \pm 1.2$ & $12.7 \pm 6.6$ \\
\hline & NO-1-B 24 & $7.4 \pm 2.4$ & $6.7 \pm 2.4$ & $4.0 \pm 1.1$ \\
\hline \multirow{3}{*}{$\begin{array}{l}\text { Bilirubin } \\
(\mu \mathrm{mol} / \mathrm{l})\end{array}$} & 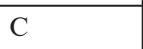 & $6.3 \pm 0.3$ & $5.3 \pm 0.2^{*}$ & $5.1 \pm 0.1^{*}$ \\
\hline & NO-1-B 12 & $5.1 \pm 0.3^{\mathrm{C}}$ & $5.0 \pm 0.6$ & $3.6 \pm 0.4^{*} \mathrm{C}$ \\
\hline & NO-1-B 24 & $5.7 \pm 0.6$ & $5.3 \pm 0.3$ & $4.0 \pm 0.7$ \\
\hline \multirow{3}{*}{$\begin{array}{l}\text { LD } \\
(\mu \text { kat } / 1)\end{array}$} & - & $7.1 \pm 2.0$ & $7.7 \pm 1.3$ & $7.8 \pm 0.8$ \\
\hline & NO-1-B 12 & $5.0 \pm 0.5$ & $5.4 \pm 0.9$ & $10.8 \pm 4.8$ \\
\hline & NO-1-B 24 & $7.1 \pm 1.9$ & $2.5 \pm 0.3^{*} \mathrm{C}$ & $8.8 \pm 1.4$ \\
\hline \multirow{3}{*}{$\begin{array}{l}\text { ALT } \\
(\mu \mathrm{kat} / \mathrm{l})\end{array}$} & C & $1.2 \pm 0.1$ & $1.2 \pm 0.1$ & $1.0 \pm 0.1$ \\
\hline & NO-1-B 12 & $1.8 \pm 0.4$ & $1.5 \pm 0.2$ & $1.4 \pm 0.3$ \\
\hline & NO-1-B 24 & $1.3 \pm 0.2$ & $1.3 \pm 0.2$ & $1.1 \pm 0.1$ \\
\hline \multirow{3}{*}{$\begin{array}{l}\text { AST } \\
(\mu \mathrm{kat} / \mathrm{l})\end{array}$} & 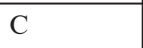 & $0.5 \pm 0.1$ & $0.6 \pm 0.1$ & $0.5 \pm 0.1$ \\
\hline & NO-1-B 12 & $0.9 \pm 0.3$ & $0.6 \pm 0.1$ & $1.7 \pm 1.1$ \\
\hline & NO-1-B 24 & $0.7 \pm 0.1$ & $0.5 \pm 0.1$ & $0.6 \pm 0.1$ \\
\hline \multirow{3}{*}{$\begin{array}{l}\text { CK } \\
(\mu \text { kat } / 1)\end{array}$} & $\mathrm{C}$ & $23.6 \pm 4.0$ & $23.7 \pm 2.6$ & $49.0 \pm 11.7^{*}$ \\
\hline & NO-1-B 12 & $17.0 \pm 1.6$ & $18.0 \pm 2.9$ & $27.2 \pm 6.3$ \\
\hline & NO-1-B 24 & $21.7 \pm 5.0$ & $9.4 \pm 1.7^{* \mathrm{C}}$ & $40.4 \pm 11.0$ \\
\hline \multirow{3}{*}{$\begin{array}{l}\text { ALP } \\
(\mu \mathrm{kat} / \mathrm{l})\end{array}$} & $\mathrm{C}$ & $3.4 \pm 0.3$ & $3.1 \pm 0.2$ & $1.6 \pm 0.1^{*}$ \\
\hline & NO-1-B 12 & $2.1 \pm 0.2^{\mathrm{C}}$ & $1.6 \pm 0.1^{*} \mathrm{C}$ & $1.4 \pm 0.1^{*}$ \\
\hline & NO-1-B 24 & $2.0 \pm 0.3^{\mathrm{C}}$ & $1.3 \pm 0.1^{*} \mathrm{C}$ & $1.1 \pm 0.1^{*} \mathrm{C}$ \\
\hline \multirow{3}{*}{$\begin{array}{l}\text { Cholesterol } \\
(\mathrm{mmol} / \mathrm{l})\end{array}$} & $\mathrm{C}$ & $1.0 \pm 0.1$ & $1.3 \pm 0.2$ & $0.8 \pm 0.1^{*}$ \\
\hline & NO-1-B 12 & $1.1 \pm 0.1$ & $1.2 \pm 0.3$ & $0.7 \pm 0.1^{*}$ \\
\hline & NO-1-B 24 & $0.8 \pm 0.1$ & $1.2 \pm 0.3$ & $0.8 \pm 0.2$ \\
\hline
\end{tabular}




\begin{tabular}{|l|l|c|c|c|}
\hline Parameter & Group & \multicolumn{3}{|c|}{ Time interval } \\
\hline & & 1. & 2. & 3. \\
\hline \multirow{2}{*}{ TG } & C & $1.0 \pm 0.1$ & $1.6 \pm 0.7$ & $1.3 \pm 0.1$ \\
$(\mathrm{mmol} / 1)$ & NO-1-B 12 & $0.8 \pm 0.1$ & $0.9 \pm 0.1$ & $1.1 \pm 0.1$ \\
& NO-1-B 24 & $0.7 \pm 0.1^{\mathrm{C}}$ & $0.6 \pm 0.1$ & $0.6 \pm 0.1^{\mathrm{CB}}$ \\
\hline \multirow{3}{*}{ Protein } & C & $62.3 \pm 1.1$ & $66.7 \pm 1.2$ & $62.0 \pm 1.5$ \\
$(\mathrm{~g} / \mathrm{l})$ & NO-1-B 12 & $58.6 \pm 0.7$ & $61.8 \pm 0.8^{\mathrm{C}}$ & $61.0 \pm 1.6$ \\
& NO-1-B 24 & $59.2 \pm 0.8$ & $60.5 \pm 1.1^{\mathrm{C}}$ & $63.4 \pm 1.4^{*}$ \\
\hline \multirow{3}{*}{ CRP } & C & $0.73 \pm 0.54$ & $1.60 \pm 0.65$ & $1.07 \pm 0.46$ \\
$(\mathrm{~g} / 1)$ & NO-1-B 12 & $4.14 \pm 1.84$ & $1.29 \pm 0.36$ & $1.86 \pm 0.40$ \\
& NO-1-B 24 & $2.00 \pm 0.5$ & $21.17 \pm 0.17$ & $1.33 \pm 0.42$ \\
\hline \multirow{2}{*}{ Albumin } & C & $46.9 \pm 0.8$ & $51.9 \pm 0.7$ & $46.2 \pm 0.9$ \\
$(\mathrm{~g} / \mathrm{l})$ & NO-1-B 12 & $42.8 \pm 0.9^{\mathrm{C}}$ & $45.2 \pm 0.3^{\mathrm{C}}$ & $45.1 \pm 1.0$ \\
& NO-1-B 24 & $43.7 \pm 0.7$ & $44.2 \pm 1.1^{\mathrm{C}}$ & $45.9 \pm 0.9^{*}$ \\
\hline
\end{tabular}

Tab. 2: Changes in haematological parameters

\begin{tabular}{|c|c|c|c|c|}
\hline \multirow[t]{2}{*}{ Parameter } & \multirow[t]{2}{*}{ Group } & \multicolumn{3}{|c|}{ Time interval } \\
\hline & & 1. & 2. & 3. \\
\hline \multirow{3}{*}{$\begin{array}{l}\text { Erythro- } \\
\text { cytes } \\
\left(10^{12} / 1\right)\end{array}$} & $\mathrm{C}$ & $5.752 \pm 0.153$ & $6.258 \pm 0.121^{*}$ & $6.215 \pm 0.132^{*}$ \\
\hline & NO-1-B 12 & $5.484 \pm 0.194$ & $5.830 \pm 0.093$ & $5.983 \pm 0.239$ \\
\hline & NO-1-B 24 & $5.845 \pm 0.184$ & $6.352 \pm 0.141$ & $6.283 \pm 0.156^{*}$ \\
\hline \multirow{3}{*}{$\begin{array}{l}\text { Haemo- } \\
\text { globin } \\
(\mathrm{g} / 1)\end{array}$} & C & $120.9 \pm 3.0$ & $136.2 \pm 1.8^{*}$ & $132.9 \pm 2.9^{*}$ \\
\hline & NO-1-B 12 & $118.9 \pm 3.5$ & $120.9 \pm 2.5^{C}$ & $123.0 \pm 4.3$ \\
\hline & NO-1-B 24 & $117.5 \pm 2.3$ & $122.8 \pm 3.1^{\mathrm{C}}$ & $128.5 \pm 3.7$ \\
\hline \multirow{3}{*}{$\begin{array}{l}\text { Haemato- } \\
\text { crit } \\
\text { (ratio) }\end{array}$} & $\mathrm{C}$ & $0.377 \pm 0.008$ & $0.421 \pm 0.007^{*}$ & $0.417 \pm 0.008^{*}$ \\
\hline & NO-1-B 12 & $0.368 \pm 0.009$ & $0.387 \pm 0.004^{\mathrm{C}}$ & $0.380 \pm 0.029$ \\
\hline & NO-1-B 24 & $0.379 \pm 0.008$ & $0.388 \pm 0.008^{C}$ & $0.393 \pm 0.011$ \\
\hline \multirow{3}{*}{$\begin{array}{l}\text { Thrombo- } \\
\text { cytes } \\
\left(10^{9} / 1\right)\end{array}$} & C & $544.3 \pm 34.6$ & $447.7 \pm 27.3^{*}$ & $448.8 \pm 29.5^{*}$ \\
\hline & NO-1-B 12 & $359.4 \pm 27.0^{C}$ & $388.9 \pm 16.3$ & $325.4 \pm 57.1$ \\
\hline & NO-1-B 24 & $405.0 \pm 69.5$ & $373.8 \pm 27.2$ & $401.2 \pm 27.0$ \\
\hline \multirow{3}{*}{$\begin{array}{l}\text { Leuco- } \\
\text { cytes } \\
\left(10^{9} / 1\right)\end{array}$} & C & $7.800 \pm 0.704$ & $6.560 \pm 0.359^{*}$ & $4.020 \pm 0.393^{*}$ \\
\hline & NO-1-B 12 & $6.571 \pm 0.298$ & $6.529 \pm 0.160$ & $4.914 \pm 1.168$ \\
\hline & B 24 & $5.417 \pm 0.425$ & $5.100 \pm 0.147^{\mathrm{C}}$ & $3.400 \pm 0.483^{*}$ \\
\hline \multirow{3}{*}{$\begin{array}{l}\text { Segmented } \\
\text { neutrophils } \\
\%\end{array}$} & $\mathrm{C}$ & $41.5 \pm 3.5$ & $36.1 \pm 2.9$ & $41.5 \pm 4.6$ \\
\hline & NO-1-B 12 & $4 \pm 4.2$ & $34.0 \pm$ & $43.4 \pm 8.4$ \\
\hline & NO-1-B 24 & $34.8 \pm 7.7$ & $37.5 \pm 3.3$ & $28.3 \pm 9.7$ \\
\hline \multirow{3}{*}{$\begin{array}{l}\text { Band } \\
\text { neutrophils } \\
\%\end{array}$} & $\mathrm{C}$ & $0.46 \pm 0.22$ & $0.33 \pm 0.19$ & $0.13 \pm 0.09$ \\
\hline & NO-1-B 12 & $7 \pm 0.30$ & $0.29 \pm 0.18$ & $0.29 \pm 0.18$ \\
\hline & NO-1-B 24 & $0.50 \pm 0.34$ & $0.17 \pm 0.17$ & $0.50 \pm 0.22$ \\
\hline \multirow{3}{*}{$\begin{array}{l}\text { Eosinophil } \\
\%\end{array}$} & $\mathrm{C}$ & $2.53 \pm 1.01$ & $0.47 \pm 0.17^{*}$ & $4.07 \pm 1.39$ \\
\hline & NO-1-B 12 & $0.43 \pm 0.30$ & $1.71 \pm 0.36^{*} \mathrm{C}$ & $3.71 \pm 0.90^{*}$ \\
\hline & B 24 & $1.17 \pm 0.83$ & $1.83 \pm 0.65^{\mathrm{C}}$ & $2.17 \pm 0.87$ \\
\hline \multirow{3}{*}{$\begin{array}{l}\text { Basophils } \\
\%\end{array}$} & C & $1.67 \pm 0.83$ & $0.67 \pm 0.25$ & $1.13 \pm 0.37$ \\
\hline & NO-1-B 12 & $0.29 \pm 0.18$ & $0.14 \pm 0.14$ & $0.71 \pm 0.29$ \\
\hline & NO-1-B 24 & $0.83 \pm 0.31$ & $0.83 \pm 0.65$ & $1.17 \pm 0.54$ \\
\hline \multirow{3}{*}{$\begin{array}{l}\text { Monocytes } \\
\%\end{array}$} & C & $2.67 \pm 0.66$ & $2.47 \pm 0.51$ & $3.53 \pm 0.70$ \\
\hline & NO-1-B 12 & $4.86 \pm 1.06$ & $4.29 \pm 1.61$ & $4.14 \pm 1.62$ \\
\hline & NO-1-B 24 & $6.67 \pm 1.94^{\mathrm{C}}$ & $4.33 \pm 1.09$ & $5.00 \pm 1.21$ \\
\hline \multirow{3}{*}{$\begin{array}{l}\text { Lympho- } \\
\text { cytes } \\
\%\end{array}$} & C & $48.5 \pm 3.8$ & $60.0 \pm 3.0^{*}$ & $49.6 \pm 4.5$ \\
\hline & $\mathrm{N}$ & $43.4 \pm 3.9$ & $59.6 \pm 9.0$ & $47.6 \pm 8.2$ \\
\hline & NO-1-B 24 & $56.0 \pm 7.9$ & $55.0 \pm 4.8$ & $55.3 \pm 4.8$ \\
\hline
\end{tabular}

LD - lactate dehydrogenase ALP - alkaline phosphatase

ALT - alanine aminotransferase TG - triglycerides

AST - aspartate aminotransferase CRP - C-reactive protein

CK - creatine kinase

* related to the initial value within a group

$\mathrm{C}$ related to the control group

B related between NO-1-B groups

\section{Haematological parameters}

There were mostly no significant differences present in haematological parameters between the NO-1-B and the control groups of rabbits. Only a mild decrease in the values of thrombocytes and leucocytes was found in NO-1$\mathrm{B}$ groups. The changes were comparable in both groups, no significant changes between the groups were found in the differential blood picture (Table 2).

\section{Biological and toxicological parameters}

There were no significant differences in the weight of animals between the groups present at the beginning of experiment $(3.19 \pm 0.07 \mathrm{~kg}$ in the control group, $3.19 \pm 0.06$ $\mathrm{kg}$ in the NO-1-B 12 group and $3.28 \pm 0.06 \mathrm{~kg}$ in the NO-1B 24 group). No significant differences were found in the weight gain of animals at the end of experiment $(24.0 \pm$ $2.4 \%$ in the control group, $17.1 \pm 1.8 \%$ in the NO-1-B 12 group and $12.8 \pm 2.9 \%$ of animals in the NO-1-B 24 group). No premature deaths were found either in the control or in the NO-1-B groups.

\section{Noninvasive polygraphic recordings of the systolic time intervals}

No significant changes during the experiment were mostly found in the control group (the values oscillated between 0.3030 and 0.3711 , i.e. $100.0-111.7 \%$ ). The dose of NO-1-B did not induce significant changes in the values of the systolic time intervals in rabbits during the whole experiment, either. The values of the PEP: LVET ratio in NO-1B 12 group were $0.4077 \pm 0.0199$ at the beginning and $0.4135 \pm 0.0286$ at the end of experiment (i.e. $101.4 \%$ ). The values in NO-1-B 24 oscillated between 0.3776 and 0.4437 during the experiment; i.e. $100.0-117.5 \%$.

\section{Discussion}

The derivatives of benfluron rank among prospective antitumour agents, which show a considerable cytolytic activity $(11,12)$. Besides antitumour activity, these substances have been studied from other aspects, e.g. the influence of dimethoxybenfluron on cell metabolic activity (6) or morphological changes caused by the derivatives of benfluron (12). Mechanisms of their effect include probably blocking cells in S and G2 phases of the cell cycle (6). Dimethoxybenfluron was also reported to induce cell lysis. Cytotoxicity of benfluron is dose-related (5) and was shown both in studies in vitro and in vivo $(11,10)$. This study was aimed to obtain a complex information about changes in some biochemical and haematological parameters following repeated administration of NO-1-B in rabbits as the changes of these parameters can often limit possible therapeutic use of new derivatives with antitumour activity.

Our study has shown that mainly no significant changes of haematological parameters occurred following repeated administration of lower doses of dimethoxybenfluron. Furthermore, only mild (though in some parameters signi- 
ficant, but within the physiological range) oscillation of the values of haematological parameters was present after the higher dose of dimethoxybenfluron. The data found in our experiment are in accordance with the results in rats published by other authors (1).

Though the administration of NO-1-B induced some significant changes in biochemical parameters, no direct relationship was found between a dose of dimethoxybenfluron and a change in the parameter. Though a mild decrease in the level of ions was mostly present, the values were not mostly significantly different in comparison with the control animals. The values of proteins and albumin did not change, or a mild increase was found during the experiment, suggesting that dimethoxybenflurons do not directly affect protein metabolism. An interesting, marked increase in the values of glucose, especially following the lower dose of dimethoxybenfluron, was found at the end of experiment. It is not possible to exclude that this increase may be related to the previously described influence of NO-1-B on the energy processes of HeL cells (7). Furthermore, the values of the other biochemical parameters mostly did not change and were not significantly different in comparison with the values in the control group (except a decrease in the values of bilirubin and ALP). Currently, this study shows that changes in some biochemical and haematological parameters following repeated administration of NO-1$\mathrm{B}$ were significantly lower in comparison with the changes after repeated administration of daunorubicin (2).

The data obtained in our study thus support the assumption of relative safety and good tolerance (13) of benfluron as well as of its derivative, dimethoxybenfluron, from the viewpoint of its influence on biochemical and haematological parameters in rabbits and may be considered of importance for a possible therapeutic use of the derivatives.

\section{Acknowledgements}

The authors wish to thank Mrs. L. Koželuhová for her skilful technical assistance and doc. B. Mánek, CSc. for revising the English text.

\section{References}

1. Berger J. A comparison of benflurone effects after intravenous infusion or oral administration. A study on laboratory rats. Folia Haematol Int Mag Klin Morphol Blutforsch 1988;115(6):797-806.

2. Geršl V, Bajgar J, Krs O et al. Changes of some biochemical and hematological parameters following administration of daunorubicin in rabbits. Sb Ved Pr Lek Fak UK Hradec Králové 1995;38:79-84.

3. Geršl V, Hrdina R. Noninvasive polygraphic cardiac changes in daunorubicin - induced cardiomyopathy in rabbits. Sb Ved Pr Lek Fak UK Hradec Králové 1994;37:49-55.

4. Geršl V, Mazurová Y, Bajgar J, Mělka M, Hrdina R, Palička V. Lack of cardiotoxicity of a new antineoplastic agent, a synthetic derivative of idenoisochinoline: comparison with daunorubicin in rabbits. Arch Toxicol 1996;70:645-51.

5. Horáková K, Jantová S, Forgacs A, Perenyi T, Lukačová D. The study of cytotoxic effect of benfluron. Neoplasma, 1988:35(2):169-76.

6. Horáková K, Lukačová D, Kozanková J, Dzurba A, Ziegelhoffer A, Jantova S The mechanism of cytolytic and cytostatic activity of benfluron. Neoplasma 1988;35(2):177-84.

7. Jantová S, Horáková K. 9-Hydroxybenfluron induced inhibition of proliferation and metabolism in HeLa cells. Cell Biochem Funct 1993;11(2)Jun:131-5.

8. Mělka M. Testování antineoplastické aktivity nových cytostatik. Dílčí úkol $03-$ Závěrečná zpráva projektu GA ČR No 303/93/20021, Farmaceutická fakulta UK v Hradci Králové, 1995:15-6.

9. Mělka M, Křepelka J. J. BENFLURON. Drugs Future 1987;12:745.

10. Mělka M, Křepelka J, Vančurová I, Řežábek K. Protinádorový účinek derivátů benzo[c]fluorenu. Cesk Fysiol 1982;31:159.

11. Mělka M, Křepelka J, Vančurová I, Pokorná S, Kejhová I, Reichlová R. Cytotoxicita, protinádorová aktivita a některé farmakolog. vlastnosti benfluronu VÚFB a některých cytostatik s interkalačním mechanismem účinku. Cesk Fysiol 1987;36:243.

12. Miko M, Křepelka J, Mělka M. Cytolytic activities of benfluron metabolites and loss of transplantability. Int J Tissue React 1989;11(3):143-51.

13. Nobilis M. Metabolity potenciálního antineoplastika benfluronu - syntéza, identifikace a stanovení. (Dissertation), 1988:36.

14. Pujman V. Vliv benfluronu na krvetvorbu. In : Benfluron. Preklinická studie, Grimová J, Křepelka J, Eds., Praha: Archiv VÚFB, 1982:412.

Submitted April 1999.

Accepted September 1999.

\author{
Mgr. Jarmila Macháčková, \\ Charles University in Prague, \\ Faculty of Medicine in Hradec Králové, \\ Department of Pharmacology, \\ Šimkova 870, 50001 Hradec Králové, \\ Czech Republic. \\ e-mail: machackovaj@lfhk.cuni.cz
}

